\title{
Genetic structure of cave-dwelling beetles populations: significant deficiencies of heterozygotes
}

\author{
Brigitte Crouau-Roy
}

\author{
Laboratoire Souterrain du CNRS, Moulis, 09200, \\ Saint-Girons, France.
}

An analysis of departure from Hardy-Weinberg equilibrium is presented for a set of three troglobitic beetles each with one larval stage (Speonomus hydrophilus, zophosinus and colluvii) from the central Pyrenees. These populations show an important deficiency of heterozygotes (positive $F_{i}$ and $F_{I S}$ values: 0.4 ) for all polymorphic loci. Several hypotheses are put forward and examined in relation with the species' biology. The local populations are highly subdivided into demes receiving limited numbers of immigrants from neighboring demes. The spatial structure of the underground environment, associated with the trapping methods used, could lead to the pooling of individuals from a number of separate demes; within these demes the close cohabitation of individuals of several generations, the lack of a larval dispersal stage, the female fertility and the rhythm of matings may give rise to an important inbreeding effect.

\section{INTRODUCTION}

The classical models of populations genetic assume that natural populations behave as panmictic units and that such populations or groups are in Hardy-Weinberg equilibrium (H-WE). In reality, natural populations are subject to disturbances of random mating relations, unlike the theoreticians' panmictic populations of infinite size in which gametic combinations occur at random; this is due to such factors as their subdivision, assortative mating, sampling fluctuations in gene frequencies, and the division of the total population range into ecologically diverse subranges with specific selective effects and limited inter-range migration (Yasuda and Morton, 1967; Selander, 1970). Nevertheless, Valenzuela (1985) thinks that "significant deviations from $\mathrm{H}-\mathrm{WE}$ have seldom been found, possibly because of the low power of the $\chi^{2}$ test used to assess H-WE" (Lewontin and Cockerham, 1959; Fairbairn and Roff, 1980). An exact knowledge of population and breeding structure is therefore important for every investigation of population genetics to permit an estimate of the degree of species and population subdivision.

This paper deals with certain aspects of the natural population structure of a species complex of troglobitic beetles ( $S$. hydrophilus, $S$. zophosinus, $S$. colluvii), and in particular with the genetic diver- gence within a population. We examine this structure on the basis of heterozygotic deviations in samples of populations using the $F$ parameters described by Wright $(1965,1969)$ and Nei $(1973$, $1986)$ in relation to their habitat and biology. These allopatric species are peculiar in exhibiting a high degree of specialisation to underground life (life cycle of one larval stage, Deleurance-Glacon, 1963) and having a very small geographical range (a few tens of square meters).

\section{MATERIALS AND METHODS}

The study was performed on the troglobitic Coleoptera genus Speonomus (Bathysciinae): $S$. hydrophilus, Jeannel, S. zophosinus, Saulcy and $S$. colluvii, Delay. Adults were collected in the Ariège (Central Pyrenees) from caves and under the deepest layer of soil and in cracks in the superficial part of the rock ("Milieu souterrain superficiel": MSS; Juberthie et al., 1980). These allopatric species are easily distinguished by male terminalia (Jeannel, 1924) and other morphological characters such as lengths of several antennal segments. Moreover these three sibling species show considerable degrees of genetic divergence (CrouauRoy, 1986). This study is based upon 23 local populations for $S$. hydrophilus, 6 for $S$. zophosinus 
and 5 for $S$. colluvii and approximately 50 to 100 animals from each locality. The local populations correspond to a group of individuals attracted by the cheese bait which is an energy source. In the cave system 2 or 3 close cheese baits are placed and only one for the MSS localities.

Electrophoresis was performed using horizontal starch gels and vertical polyacrylamide gel depending upon the enzyme. Nine polymorphic loci were studied: esterase (Est-6), leucine aminopeptidase (Lap-1), phosphohexose isomerase $(P h i-1)$, acid phosphatase $(P a c-1)$, malic enzyme $(\mathrm{Me})$, hexokinases $(H k-3, H k-4)$, malate dehydrogenase $(M d h)$ and $\alpha$ glycerophosphate dehydrogenase $(\alpha-G p d h)$. Buffers and staining procedures are described in Crouau-Roy (1986).

Genotypic frequencies were determined for each locus within each population and these were compared to expected Hardy-Weinberg proportions. The differences between the observed and expected values can be tested, using a $\chi^{2}$, or G-test (Sokal and Rohlf, 1969) if the expected values are small $G=2 \sum_{1}^{h} x_{\text {obs }}^{i} \ln \left(x_{\text {obs }}^{i} / x_{\text {exp }}^{i}\right)$, with a number of degrees of freedom calculated as $\frac{1}{2}\left(k^{2}-k\right)$ where $k$ is the number of alleles.

The genotypic fixation index (Wright, 1965; Nei, 1973; Eanes and Koehn, 1978) was calculated for each population, and measures the relative difference between $\mathrm{He}$ and Ho: $F_{i}=$ $(\mathrm{He}-\mathrm{Ho}) / H_{\exp }$ where $\mathrm{He}$ is the expected proportion of heterozygotes and Ho the observed proportion of heterozygotes, for population $i$. $F_{I S}$ is the average over all subdivisions of the correlation between uniting gametes relative to those of their own subdivision; it is calculated as a weighted average of $F_{i}: F_{I S}=\sum w_{i} p_{i}\left(1-p_{i}\right) F_{i} / \sum w_{i} p_{i}\left(1-p_{i}\right)$ where $w_{i}$ is the proportion of the total sample represented by population $i\left(\sum_{i} w_{i}=1\right)$ and $p_{i}$ is the mean frequency of the common allele in the pooled sample (Wright, 1965; Kirby, 1975). The average fixation index $F_{I S}$ reflects the joint effect of any forces which might act on the pattern of genetic variation at the level of the sub-divisions, and denotes the deviation from Hardy-Weinberg proportions. When inbreeding is the only factor, $F_{i}$ is identical with the classical inbreeding coefficient $f$.

\section{RESULTS}

All the polymorphic loci show a disequilibrium in the genotypic proportions in comparison with expected values under Hardy-Weinberg assumptions. These deviations were observed in all local populations of the 3 species and for all loci. Table 1 gives a comparison of the observed and theoretical phenotypes for the populations of $S$. zophosinus. In order to test for genotypic heterogeneity among populations, statistical estimations using a $\chi^{2}$-test or G-test were performed for each of the polymorphic loci (table 2), showing sifinficant differences between observed genotypic frequencies and those expected under $\mathrm{H}-\mathrm{WE}$. In all cases, the significance is due to an excess of homozygotes.

The observed and expected heterozygosities and the population fixation indices $\left(F_{i}\right)$ of the individual populations of $S$. hydrophilus, $S$. zophosinus and $S$. colluvii show a significant deficiency of heterozygosity, and all $F_{i}$ values are positive (see table 2 for $S$. zophosinus). However, because of the small sample sizes in some of the populations, in particular of $S$. colluvii $(<30$ animals), one must be careful in interpreting trends toward excesses or deficiencies of heterozygotes from the raw $F_{i}$ values. We considered the weighted mean of the $F_{i}$ (denoted by $F_{I S}$ ), which measures deviation of the heterozygote proportions from $\mathrm{H}$-WE expectations, to reduce the effects of the stochastic variation. Table 3 presents mean observed and expected heterozygosities and population fixation indices $F_{I S}$ and $F_{I T}$ based on all local populations. For all the loci, the mean observed heterozygosity is less than expected on the assumption of $\mathrm{H}-\mathrm{WE}$. The 3 species show large positive values of $F_{I S}$ for all loci which are nearly identical ( $S$. hydrophilus: $0.442 \mp 0.020 ; S$. zophosinus: $0.432 \mp 0.026$ and $S$. colluvii: $0.442 \mp$ $0 \cdot 019)$.

\section{DISCUSSION}

The deficiencies of heterozygotes (positive $F_{i}$ and $F_{I S}$ values) found for all polymorphic loci and at all sites are inconsistent with a panmictic population in $\mathrm{H}-\mathrm{WE}$, and the 3 species do not differ in within-population deviations from panmixie as measured by $F_{I S}$.

Many studies exhibit significant deficiencies in natural populations, but generally these deficiencies are observed at some allozymic loci and/or in only some samples with an equilibrium distribution at the other polymorphic loci studied and within a single species, different loci do not show the same deficiency of heterozygotes. This observation is common for populations of several marine bivalves (Zouros et al., 1980; Beaumont, 1982; Berger, 1983; Singh and Green, 1984; Zouros 
Table 1 Comparison of the observed and theoretical phenotypes at five enzyme loci in local populations of $S$. zophosinus. $N=$ sample size. Loci are numbered with respect to increasing anodal migration

\begin{tabular}{|c|c|c|c|c|c|c|c|}
\hline & & LACO & CROI & MURA & PONT & CLOU & QUER \\
\hline & $\mathrm{N}$ & 338 & 109 & 48 & 92 & 128 & 129 \\
\hline \multirow[t]{21}{*}{ Est- 6} & 84 & $215(187 \cdot 14)$ & $50(41 \cdot 80)$ & $30(27 \cdot 76)$ & - & - & - \\
\hline & 86 & $39(15 \cdot 12)$ & $19(11 \cdot 24)$ & $4(2 \cdot 08)$ & - & - & - \\
\hline & 88 & $6(0.67)$ & $3(0.39)$ & $1(0.05)$ & $2(0.39)$ & $2(0.05)$ & $3(0.38)$ \\
\hline & 90 & - & - & - & $46(38 \cdot 48)$ & $21(11 \cdot 58)$ & $29(16.05)$ \\
\hline & 92 & - & - & - & $8(6 \cdot 26)$ & $56(43 \cdot 36)$ & $50(37.98)$ \\
\hline & 94 & - & - & - & $0(0.07)$ & $8(1.22)$ & $3(0.33)$ \\
\hline & $84 / 86$ & $60(106 \cdot 40)$ & $30(43.35)$ & $12(15 \cdot 21)$ & - & - & - \\
\hline & $84 / 88$ & $13(22 \cdot 32)$ & $5(8 \cdot 05)$ & $1(2 \cdot 28)$ & - & - & - \\
\hline & $84 / 90$ & - & - & - & - & - & - \\
\hline & $84 / 92$ & - & - & - & - & - & - \\
\hline & $84 / 94$ & - & - & - & - & - & - \\
\hline & $86 / 88$ & $5(6 \cdot 35)$ & $2(4.17)$ & $0(0.63)$ & - & - & - \\
\hline & $86 / 90$ & - & - & - & - & - & - \\
\hline & $86 / 92$ & - & - & - & - & - & - \\
\hline & $86 / 94$ & - & - & - & - & - & - \\
\hline & $88 / 90$ & - & - & - & $4(7.76)$ & $1(1 \cdot 5)$ & $2(4.94)$ \\
\hline & $88 / 92$ & - & - & - & $4(3 \cdot 13)$ & $0(2 \cdot 9)$ & $6(7 \cdot 6)$ \\
\hline & $88 / 94$ & - & - & - & $0(0.33)$ & $0(0.49)$ & $0(0.71)$ \\
\hline & $90 / 92$ & - & - & - & $23(31 \cdot 04)$ & $31(44.82)$ & $29(49.38)$ \\
\hline & $90 / 94$ & - & - & - & $0(3 \cdot 23)$ & $3(7 \cdot 52)$ & $2(4.59)$ \\
\hline & $92 / 94$ & - & - & - & $5(1.30)$ & $6(14.55)$ & $5(7.05)$ \\
\hline \multirow[t]{4}{*}{ Lap-1 } & $\mathbf{N}$ & 159 & 67 & 52 & 68 & 174 & 128 \\
\hline & 100 & $120(106 \cdot 29)$ & $49(44 \cdot 33)$ & $38(34 \cdot 74)$ & $44(38 \cdot 25)$ & $112(95 \cdot 64)$ & $83(71 \cdot 25)$ \\
\hline & 102 & $19(5 \cdot 29)$ & $7(2 \cdot 33)$ & $5(1.74)$ & $10(4 \cdot 25)$ & $28(11 \cdot 64)$ & $20(8 \cdot 25)$ \\
\hline & $100 / 102$ & $20(47 \cdot 42)$ & $11(20 \cdot 34)$ & $9(15 \cdot 53)$ & $14(25 \cdot 50)$ & $34(66 \cdot 72)$ & $25(48 \cdot 50)$ \\
\hline \multirow[t]{4}{*}{ Phi-1 } & $\mathrm{N}$ & 93 & 65 & 61 & 75 & 126 & \\
\hline & 96 & $77(72 \cdot 30)$ & $52(49 \cdot 11)$ & $48(45 \cdot 18)$ & $57(52 \cdot 92)$ & $99(90 \cdot 87)$ & $70(64 \cdot 31)$ \\
\hline & 98 & $6(1 \cdot 30)$ & $4(1 \cdot 11)$ & $4(1 \cdot 18)$ & $6(1.92)$ & $11(2 \cdot 87)$ & $8(2 \cdot 31)$ \\
\hline & $96 / 98$ & $10(19 \cdot 40)$ & $9(14 \cdot 78)$ & $9(14 \cdot 63)$ & $12(20 \cdot 16)$ & $16(32 \cdot 27)$ & $13(24 \cdot 38)$ \\
\hline \multirow[t]{4}{*}{$P a c-1$} & $\mathrm{~N}$ & 70 & 46 & 40 & 43 & 88 & 67 \\
\hline & 98 & $66(65.09)$ & $44(43 \cdot 05)$ & $40(40 \cdot 00)$ & $43(43 \cdot 00)$ & $88(88.00)$ & $67(67 \cdot 00)$ \\
\hline & 100 & $1(0.09)$ & $1(0.05)$ & - & - & - & - \\
\hline & $98 / 100$ & $3(4 \cdot 82)$ & $1(2.90)$ & 一 & - & - & - \\
\hline \multirow[t]{4}{*}{$M e$} & $\mathrm{~N}$ & 105 & 51 & 40 & 42 & 110 & 69 \\
\hline & 98 & $3(0.34)$ & $1(0 \cdot 24)$ & $1(0 \cdot 10)$ & $1(0 \cdot 10)$ & $3(0.33)$ & $1(0 \cdot 13)$ \\
\hline & 100 & $96(93 \cdot 34)$ & $45(44 \cdot 24)$ & $37(36 \cdot 10)$ & $39(38 \cdot 10)$ & $101(98 \cdot 33)$ & $64(63 \cdot 13)$ \\
\hline & $98 / 100$ & $6(11 \cdot 31)$ & $5(6.52)$ & $2(3 \cdot 80)$ & $2(3 \cdot 81)$ & $6(11 \cdot 35)$ & $4(5 \cdot 74)$ \\
\hline
\end{tabular}

and Foltz, 1984; Foltz, 1986), crustaceans (Singh and Zouros, 1978; Berger and Sutherland, 1978; Hedgecock et al., 1977; Sassaman, 1978; Beck and Price, 1981, 1985; Mort and Wolf, 1985), for other animals (Black and Krafsur, 1985; Snyder and Lynton, 1984; Sturgeon and Mitton, 1986) and for plants (Sytsma and Schaal, 1985). These deficiencies have usually been explained by invoking inbreeding, assortative mating, differential genotypic selection, null alleles or population structure (the Wahlund effect).

For these cave dwelling Coleopterae, several hypotheses were examined in an attempt to account for these observations in relation with the species' biology.

\section{Null alleles}

Null or silent alleles do not give any band on the zymogram, so a heterozygote for a null allele will be scored as an active homozygote. This would lead to apparent heterozygote deficiencies. It appears unlikely that such alleles segregate at all the polymorphic loci of these 3 species; nevertheless we have calculated the frequencies of null alleles required to explain the deficiencies of heterozygotes by the method of Zouros and Krimbas (1969) suitable for the estimation of null alleles in a multiallelic system (table 4). These frequencies vary from 0.091 to 0.367 according to the loci and the species. Individuals which are 
Table 2 Observed heterozygosity (Ho), expected heterozygosity (He) and genotypic fixation index (Fi) for polymorphic loci of the 6 local populations of $S$. zophosinus. Values of the $\chi^{2}$ or G-test for the comparisons between the frequencies of observed and expected genotypes. Degrees of freedom in parentheses. $P<0.01$

\begin{tabular}{|c|c|c|c|c|c|c|c|}
\hline & & Lacourt & $\begin{array}{l}\text { Croix de } \\
\text { la Quère }\end{array}$ & Murassé & Pontaud & Cloutet & $\begin{array}{l}\text { Quer de } \\
\text { Massat }\end{array}$ \\
\hline Est -6 & $\begin{array}{l}\mathrm{Ho} \\
\mathrm{He} \\
\mathrm{Fi} \\
\chi^{2}\end{array}$ & $\begin{array}{c}0 \cdot 23 \\
0 \cdot 40 \\
0 \cdot 42 \\
74 \cdot 8(3)\end{array}$ & $\begin{array}{c}0.34 \\
0.51 \\
0 \cdot 34 \\
42 \cdot 5(3)\end{array}$ & $\begin{array}{c}0.27 \\
0.38 \\
0.28 \\
26.7(3)\end{array}$ & $\begin{array}{c}0.39 \\
0.51 \\
0 \cdot 23 \\
15 \cdot 2(6)\end{array}$ & $\begin{array}{c}0.32 \\
0 \cdot 56 \\
0 \cdot 43 \\
19 \cdot 4(6)\end{array}$ & $\begin{array}{c}0.34 \\
0.58 \\
0 \cdot 41 \\
36 \cdot 3(6)\end{array}$ \\
\hline Lap-1 & $\begin{array}{l}\mathrm{Ho} \\
\mathrm{He} \\
\mathrm{Fi} \\
\chi^{2}\end{array}$ & $\begin{array}{c}0 \cdot 13 \\
0 \cdot 30 \\
0 \cdot 58 \\
43 \cdot 2(1)\end{array}$ & $\begin{array}{c}0.16 \\
0.30 \\
0 \cdot 46 \\
11 \cdot 7(1)\end{array}$ & $\begin{array}{l}0 \cdot 17 \\
0 \cdot 30 \\
0 \cdot 42 \\
7 \cdot 6(1)\end{array}$ & $\begin{array}{c}0.21 \\
0.37 \\
0.45 \\
12 \cdot 6(1)\end{array}$ & $\begin{array}{c}0 \cdot 19 \\
0 \cdot 38 \\
0 \cdot 49 \\
38 \cdot 7(1)\end{array}$ & $\begin{array}{c}0 \cdot 19 \\
0 \cdot 38 \\
0.48 \\
27 \cdot 6(1)\end{array}$ \\
\hline$P h i$ & $\begin{array}{l}\mathrm{Ho} \\
\mathrm{He} \\
\mathrm{Fi} \\
\chi^{2}\end{array}$ & $\begin{array}{c}0 \cdot 11 \\
0 \cdot 21 \\
0 \cdot 48 \\
14 \cdot 8(1)\end{array}$ & $\begin{array}{c}0 \cdot 14 \\
0 \cdot 23 \\
0 \cdot 39 \\
17 \cdot 2(1)\end{array}$ & $\begin{array}{c}0 \cdot 15 \\
0.24 \\
0 \cdot 38 \\
16 \cdot 2(1)\end{array}$ & $\begin{array}{l}0 \cdot 16 \\
0 \cdot 27 \\
0 \cdot 40 \\
9 \cdot 7(1)\end{array}$ & $\begin{array}{c}0 \cdot 14 \\
0 \cdot 26 \\
0 \cdot 44 \\
24 \cdot 1(1)\end{array}$ & $\begin{array}{c}0 \cdot 14 \\
0 \cdot 27 \\
0 \cdot 47 \\
15 \cdot 4(1)\end{array}$ \\
\hline$M e$ & $\begin{array}{l}\mathrm{Ho} \\
\mathrm{He} \\
\mathrm{Fi} \\
\chi^{2}\end{array}$ & $\begin{array}{c}0.06 \\
0 \cdot 11 \\
0 \cdot 47 \\
10 \cdot 8(1)\end{array}$ & $\begin{array}{l}0 \cdot 05 \\
0 \cdot 13 \\
0 \cdot 23 \\
2 \cdot 7(1)\end{array}$ & $\begin{array}{l}0.05 \\
0.09 \\
0.47 \\
3.9(1)\end{array}$ & $\begin{array}{l}0.05 \\
0.09 \\
0.47 \\
3.8(1)\end{array}$ & $\begin{array}{c}0.06 \\
0 \cdot 10 \\
0 \cdot 47 \\
10 \cdot 6(1)\end{array}$ & $\begin{array}{l}0.08 \\
0.30 \\
2.9(1)\end{array}$ \\
\hline$P a c-1$ & $\begin{array}{l}\mathrm{Ho} \\
\mathrm{He} \\
\mathrm{Fi} \\
\chi^{2}\end{array}$ & $\begin{array}{l}0.04 \\
0.07 \\
0 \cdot 38 \\
3 \cdot 8(1)\end{array}$ & $\begin{array}{l}0.02 \\
0.06 \\
0.65 \\
5.8(1)\end{array}$ & $\begin{array}{l}0.000 \\
0.000 \\
0 \\
-\end{array}$ & $\begin{array}{l}0.000 \\
0.000 \\
0 \\
-\end{array}$ & $\begin{array}{l}0.000 \\
0.000 \\
0 \\
-\end{array}$ & $\begin{array}{l}0.000 \\
0.000 \\
0 \\
-\end{array}$ \\
\hline
\end{tabular}

Table 3 Observed and expected heterozygosities ( $\mathrm{Ho}, \mathrm{He})$, results of the analysis of $\mathrm{F}$. statistics $\left(F_{I S}, F_{I T}, F_{S T}\right)$ and heterogeneity Chi-square among populations for each variable loci of the three species. n.s. = non-significative

\begin{tabular}{|c|c|c|c|c|c|c|c|}
\hline & Locus & Ho & $\mathrm{He}$ & $F_{I S}$ & $F_{I T}$ & $F_{S T}$ & $\chi^{2}$ \\
\hline \multirow{7}{*}{$\begin{array}{l}\text { S. hydrophilus } \\
\text { (23 populations) }\end{array}$} & Est 6 & 0.293 & 0.520 & 0.409 & 0.556 & $0 \cdot 249$ & $1022 \cdot 39$ \\
\hline & Lap-1 & $0 \cdot 211$ & $0 \cdot 342$ & $0 \cdot 365$ & 0.497 & $0 \cdot 208$ & 601.95 \\
\hline & Phi & $0 \cdot 320$ & 0.541 & 0.405 & 0.452 & $0 \cdot 080$ & $347 \cdot 84$ \\
\hline & $M e$ & $0 \cdot 018$ & 0.040 & 0.520 & 0.542 & $0 \cdot 047$ & 137.89 \\
\hline & $P a c-1$ & 0.009 & 0.019 & 0.447 & 0.475 & 0.052 & $140 \cdot 29$ \\
\hline & $H k-3$ & 0.012 & 0.027 & 0.456 & 0.492 & 0.068 & $192 \cdot 71$ \\
\hline & $H k-4$ & 0.006 & 0.011 & 0.545 & 0.582 & 0.083 & $218 \cdot 29$ \\
\hline \multicolumn{2}{|l|}{$\begin{array}{l}\text { Mean } \\
\quad \text { (Stand-error) }\end{array}$} & $\begin{array}{c}0 \cdot 124 \\
(0 \cdot 055)\end{array}$ & $\begin{array}{l}0.214 \\
(0.93)\end{array}$ & $\begin{array}{l}0.450 \\
(0.024)\end{array}$ & $\begin{array}{c}0.514 \\
(0 \cdot 018)\end{array}$ & $\begin{array}{c}0.112 \\
(0.031)\end{array}$ & \\
\hline \multirow{5}{*}{$\begin{array}{l}\text { S. zophosinus } \\
\text { (6 populations) }\end{array}$} & Est -6 & $0 \cdot 316$ & 0.489 & $0 \cdot 351$ & 0.581 & 0.354 & $597 \cdot 55$ \\
\hline & Lap-1 & $0 \cdot 177$ & $0 \cdot 340$ & $0 \cdot 481$ & 0.483 & 0.005 & 6.48 n.s. \\
\hline & $P h i$ & $0 \cdot 140$ & $0 \cdot 245$ & 0.428 & 0.430 & 0.004 & 4.08 n.s. \\
\hline & $M e$ & 0.061 & $0 \cdot 101$ & 0.403 & 0.403 & 0.000 & 0 n.s. \\
\hline & $P a c-1$ & $0 \cdot 011$ & 0.022 & 0.497 & 0.518 & 0.043 & $30 \cdot 44$ \\
\hline \multicolumn{2}{|l|}{$\begin{array}{l}\text { Mean } \\
\quad \text { (Standard-error) }\end{array}$} & $\begin{array}{l}0 \cdot 141 \\
(0.053)\end{array}$ & $\begin{array}{c}0 \cdot 239 \\
(0 \cdot 089)\end{array}$ & $\begin{array}{c}0.432 \\
(0.026)\end{array}$ & $\begin{array}{c}0.483 \\
(0.032)\end{array}$ & $\begin{array}{c}0.081 \\
(0.069)\end{array}$ & \\
\hline \multirow{7}{*}{$\begin{array}{l}\text { S. colluvii } \\
\quad(5 \text { populations })\end{array}$} & Est- 6 & 0.324 & 0.510 & 0.367 & $0 \cdot 379$ & 0.019 & 4.67 n.s. \\
\hline & Lap-1 & $0 \cdot 214$ & $0 \cdot 416$ & $0 \cdot 486$ & 0.546 & $0 \cdot 118$ & $36 \cdot 46$ \\
\hline & Phi & $0 \cdot 209$ & $0 \cdot 380$ & $0 \cdot 442$ & 0.448 & 0.012 & 4.48 n.s. \\
\hline & $M d h$ & $0 \cdot 256$ & $0 \cdot 480$ & 0.468 & 0.477 & 0.018 & 6.76 n.s. \\
\hline & $H k-3$ & $0 \cdot 316$ & 0.568 & 0.443 & 0.449 & 0.012 & 4.96 n.s. \\
\hline & $H k-4$ & $0 \cdot 188$ & $0 \cdot 299$ & $0 \cdot 385$ & 0.485 & $0 \cdot 164$ & $61 \cdot 66$ \\
\hline & Gpdh & $0 \cdot 212$ & $0 \cdot 458$ & 0.507 & 0.539 & 0.006 & $2 \cdot 20$ n.s. \\
\hline \multirow{2}{*}{\multicolumn{2}{|c|}{$\begin{array}{l}\text { Mean } \\
\quad \text { (Standard error) }\end{array}$}} & $0 \cdot 246$ & $0 \cdot 444$ & $0 \cdot 444$ & 0.475 & 0.050 & \\
\hline & & $(0.021)$ & $(0 \cdot 033)$ & $(0 \cdot 020)$ & $(0 \cdot 022)$ & $(0.024)$ & \\
\hline
\end{tabular}


homozygous for a silent allele therefore would have to appear with frequencies sometimes reaching 15 per cent. No null homozygotes were observed, which may be considered as a strong evidence aginst this explanation. Nevertheless, Foltz (1986) thinks that in some cases, this absence is explained by assuming that null homozygotes are lethal or semilethal but this may be true only if their frequency is low.

Table 4 Frequency of null alleles under the assumption of no selection

\begin{tabular}{llll}
\hline & S. hydrophilus & S. zophosinus & S. colluvii \\
\hline Est-6 & 0.367 & 0.187 & 0.135 \\
Lap-1 & 0.214 & 0.216 & 0.191 \\
Phi-1 & 0.238 & 0.298 & 0.185 \\
Pac-1 & 0.148 & 0.091 & - \\
Me & 0.136 & 0.127 & - \\
Hk-3 & 0.315 & - & 0.193 \\
Hk-4 & 0.168 & - & 0.151 \\
Mdh & - & - & 0.224 \\
Gpdh & - & - & 0.239 \\
\hline
\end{tabular}

\section{Sampling of two species}

A marked excess of homozygotes will appear in a sample if it contained individuals from different sibling species showing the same alleles with different frequencies. But it seems an unlikely explanation because it would require a cohabitation of these species across all the range of the 3 Speonomus taxa. In addition, comparison of population gene frequencies and individual genotypes does not indicate that two different species were involved.

\section{Assortative mating}

The existence of nonrandom mating could explain the observed heterozygote deficiency for the characters under mating selection (Karlin and Feldman, 1968). The positive genotypic homogamy may be total or partial. This seems improbable, unless all loci are linked or otherwise associated, that the assortative matings were the principal cause of these deficiencies. We cannot rule out the possibility of a linkage desequilibrium for two reasons: breeding studies have proven difficult or impossible with these species because matings are rare under laboratory conditions; further, the size of the animals limits the number of electrophoretic loci that can be studied in a single individual to one or two.

\section{Inbreeding and structuration of the populations}

Inbreeding can result from matings between relatives with different degrees of relatedness. However, in most natural populations, the proportion of between-relative matings is not known, except for humans (e.g., Cavalli-Sforza and Bodmer, 1971). Mating between relatives may result in effects on genetic variation in a population and affects all loci in a uniform way in contrast with the previous hypothesis: with no selection, one effect of inbreeding is to increase the probability of homozygosity due to identity by descent. When there is selection, the effects are more complicated (see Hedrick, 1985 for a review).

Several observations indicate that inbreeding is possible in these specialised species. First, there is homogeneity of the fixation indices $F_{I S}$ at the polymorphic loci whatever the heterozygosity. Second, inbreeding is apparently compatible with the species biology because of the characteristics of reproduction which may lead to close cohabitation of individuals of several generations. We can estimate the adult life at 3-4 years. The life-cycle of $S$. zophosinus lasts about 10 months and, in laboratory culture, egg-laying and emergence occur throughout the whole year (Juberthie et al., 1981). Gametes from closely related individuals are likely to combine in frequencies higher than expected by chance because there is lack of larval feeding and no larval dispersal stage. Thus generation overlap in natural populations is possible and this would allow some patterns of reproduction and possibly of selection, much more complex than in the case of discrete generations.

Nevertheless, we have no idea of the reality of the generation overlap. In effect, when a population is age-structured, we do not know the effect of ageing on the receptivity of the females and on mating capacity. The experiments of marking and recapture indicate large numbers of Speonomus (several thousands). However this is not a sure indicator of a large effective population size which is important on the genetic structure. Indeed, the effective population size influences the dynamics of genetic structure under natural selection since the probability and rate of fixation of a selectively advantageous mutant is an inverse function of effective size (Kimura and Ohta, 1971).

Intermediate but still primitive life cycle Speonomus like $S$. delarouzeei (two larval stages) do not exhibit deficiency of heterozygotes (Delay et al., 1980). These Speonomus are known to undergo multiple mating and to store sperm for long periods (Juberthie-Jupeau and Cazals, 1984). 
Such multiple matings and sperm storage may reduce the amount of inbreeding and increase the effective population size (Murray, 1964). In the studied species, the frequency of observed matings in the cave-laboratory is rare $(\sim 5$ per cent) and there is a reduction in numbers of eggs laid by the female. These differences in female fertility and the rhythm of matings between the one and two larval stage species may lead to a different population structure. If there is a constant level of inbreeding in each generation, then the heterozygosity (different among loci and species) would approach an equilibrium value resulting from reduction of heterozygosity by inbreeding in the case of no selection. This is as yet unclear.

Inbreeding may be consolidated by the structure of the environment and the utilization of the space of an aggregative manner in the zones where food is available. These Coleoptera have a limited dispersal potential, they live under the deepest layer of soil, in cracks in the superficial part of rock. Subterranean communities are food-limited (Howarth, 1983) and the energy sources are patchily distributed and depend of the epigean primariy productivity (vegetation), the availability of agents for the transport of energy (e.g., water and animals) and the geological structure of the underground. These patches and the Speonomus' behavior with regards to energy sources may lead to a structuration of the populations. The technique of baiting presumably attracts beetles over a wide area within each cave. Thus it is possible that collection may contain individuals attracted from more than one "breeding colony" within the cave system. Spatial structure of the underground associated with this technique of baiting could lead to the pooling of individuals from a number of separate demes. The "Walhund effect" appears when the populations or taxa show at least partial reproductive isolation. This hypothesis does not require strong genetic differentiation. The pooling of distinct populations that differ in electromorph frequency may be a cause of an observed heterozygote deficiency.

This study reveals an important structuration of the local populations: the individuals are not homogeneously distributed in space and they exist in more or less well-defined clusters or demes. The boundaries between these demes may be deduced from the formula $F=1 /(4 \mathrm{Nm}+1)$ of the "island model" (Wright, 1943) with $m$ the effective proportion of the population exchanged between local populations every other generation and $N$ the effective population number in the deme. With the fixation index $F_{I S} \simeq 0.4$ we may estimate $N m \simeq 0.4$. The local populations of these troglobitic beetles correspond to a group of individuals from several demes receiving limited numbers of immigrants from neighboring demes and attracted by the energy source which is here the cheese bait. A low rate of migration represents an important degree of isolation among local demes, and since processes, such as inbreeding and/or even partial assortative mating, limit the effective breeding population, any departure from random mating coupled with limital dispersal ability in Speonomus would result in an increase in homozygotes at the expense of heterozygotes.

The results of these investigations point out the difficulties inherent in any attempt to deduce the degree and characteristics of matings and the extent of subdivision in natural populations only on the basis of heterozygotic deviations in samples. This study shows that one must take account of the life history, the population structure (in particular the effects of population subdivision on genetic differentiation), the aspects of the genetic organization and the biology of the beetles in order to be able to understand the population structure of a species.

Acknowledgments I would particularly like to thank Dr. Chris Gliddon, Dr. P. H. Gouyon and Dr. D. Anxolabehere for their valuable discussions and for their critical review of the manuscript. I would also like to acknowledge and thank Miss C. Ferre for technical assistance and Mrs F. Boineau for typing the manuscript.

\section{REFERENCES}

BEAUMONT, A. R. 1982. Variations in heterozygosity at two loci between year classes of a population of Chlamys opercularis from a Scottish sea-loch Mar. Biol. Lett. 3, 25-34.

BECK, M. L. AND PRICE, J. O. 1981. Genetic variation in the terrestrial isopod, Armadillidium vulgare. The Journal of Heredity, 72, 15-18.

BECK, M. L. AND PRICE, J. O. 1985. Genetic variation and differentiation in Armadillidium vulgare (Isopoda: Oniscoidea). Genetica, 66, 169-171.

BERGER, E. N. AND SUTHERLAND, J. 1978. Allozyme variation in two natural populations of Daphnia pulex. Heredity, 41 , 13-23.

BERGER. E. M. 1983. Population genetics of marine gastropods and bivalves, 563-596. In Russel-Hunger, W. D. (ed.) The Mollusca, Vol. 6, Ecology, Academic Press. N.Y.

BLACK, W. C. AND KRAFSUR, E. S. 1985. Electrophoretic analysis of genetic variability in the house fly (Musca domestica L.). Biochemical Genetics, 23, 3-4, 193-203.

CAVALLI-SFORZA, L. L. AND BODMER, W. F. 1971. The genetics of Human Populations. Freeman, San Francisco, CA. 
CrouAu-ROY, B. 1986. Structure génétique des populations et des espèces chez des coléoptères troglobies (Speonomus). Etude des mécanismes de spéciation. Thèse d'Etat, University of Montpellier, pp. 1-300.

DELAY, B., SBORIDONI, V., COBOLLI-SBORDONI, M. AND DE MATTHAEIS, E. 1980. Divergences génétiques entre les populations de Spenomus delarouzeei du Massif du Canigou (Coleoptera, Bathysciinae). Mémoires de Biospéologie, 7, 235-247.

DELEURANCE-GLACON, S. 1963. Recherches sur les Coléoptères troglobies de la sous famille des Bathysciinae. Ann. Sci. nat. Zool., 12, 1-172.

EANES, W. F. AND KOEHN, R. K. 1978. An analysis of genetic structure in the monarch butterfly, Danaus plexippus L. Evolution, 32, 784-797.

Gregorius (ed.), Population Genetics in Forestry. SpringerVerlag, N.Y.

HEDRICK, P. W. 1986. Average inbreeding or inbreeding equilibrium. Amer. J. Hum. Genet., 38, 538-557.

HowarTh, F. G. 1983. Ecology of cave Arthropods. Ann. Rev. Entomol., 28, 365-389.

JEANNEL, R. 1924. Monographie des Bathysciinae. Biospeologica. Arch. zool. exp. gén., 63, 1, 436.

JUBERTHIE, C., DELAY, B. AND BOUILlON, M. 1980. Sur l'existence d'un milieu souterrain superficiel en zone non calcaire. C. R. Acad. Sci., 290, 49-52.

JUBERTHIE, C., DELAY, B., DURAND, J., JUBERTHIE-JUPEAU, L., BOUILLON, M. AND RUfFAT G. 1981. Etude écologique morphologique, biométrique et biologique de Speonomus zophosinus (Coléoptères Bathysciinae). Mém. Biospéol., VIII, p. 95-124.

JUBERTHIE-JUPEAU, L AND CAZALS, M. 1984. Modalités de l'accouplement dans différentes populations du complexe Spenomous delarouzeei. Mém. Biospéol., 11, 165-172.

KARLIN, S. AND FELDMAN M. W. 1968. Analysis of models homozygotes, heterozygotes matings. Genetics, 59, 117136.

KIMURA, M AND OHTA, T. 1971. Theoretical aspects of population genetics. Princeton Univ. Press, Princeton.

KIRBY, G. C. 1975. Heterozygote frequencies in small subpopulations. Theoretical Population Biology, 8, 31-48.

LEWONTIN, R. C. AND COCKERHAM, C. 1959. The goodness of fit for detecting natural selection in random mating populations. Evolution, 13, 561-564.

MORT, M. A. AND WOLF, H. G. 1985. Enzyme variability in large-lake Daphnia populations. Heredity, 55, 27-36.

MURRAY. J. 1964. Multiple mating and effective population size in Cepaea memoralis. Evolution, 18, 284-291.

NEI, M. 1973. Analysis of gene diversity in subdivided populations. Proc. Nat. Acad. Sci., USA, 70, 3321-3323.

NEI, M. 1986. Definition and estimation of fixation indices. Evolution, 40, 643-645.
SASSAMAN, C. 1978. Dynamics of a lactate dehydrogenase polymorphism in the wood louse Porcellio scaber latr. Evidence for partial assortative mating and heterosis in natural populations. Genetics, 88, 591-609.

SELANDER, R. K. 1970. Behavior and genetic variation in natural populations. Amer. Zool, , 10, 53-66.

SINGH, S. M. AND GREEN R. H. 1984. Excess of allozyme homozygosity in marine molluscs and its possible biological significance. Malacologia, 25, 569-581.

SINGH, S. M. AND ZOUROS, E. 1978. Genetic variation associated with growth rate in the American oyster (Crassostrea virginica). Evolution, 32, 342-353.

SNYDER, T. P. AND LINTON, M. C. 1984. Population structure in black flies: allozymic and morphological estimates for Prosimulium mixtum and P. fluxum (Diptera: Simuliidae). Evolution, 38, 942-946.

SOKAL, R. R. AND ROHLF, F. 1969. Biometry: the principles and practice of statistics in biological research. Freeman, San Francisco.

STURGEON, K. B. AND MITTON, J. B. 1986. Allozyme and morphological differentiation of mountain pine beetles Dentroctomus ponderosae hopkins (Coleoptera: Scolytidae) associated with host tree. Evolution, 40, 290 302.

VAlenzUela, C. Y. 1985. Algebraic and epistemological restrictions in studies on Hardy-Weinberg equilibrium. Am. Naturalist, 125, 744-746.

YASUDA, N. AND MORTON, N. E. 1967. Studies on human population structure. In Crow, J. F. and Neel, J. U., Proceedings on the third international Congress of human genetics: polenary sessions and symposia John Hopkins. Univ. Press Baltimore, 245-265.

zOUROS, E. AND KRIMBAS, C. B. 1969. The genetics of Dacus olae. III. Amount of variation at two esterase loci in a Greek population. Genet. Res., 14, 249-258.

ZOUROS, E., SINGH, S. M. AND MILES, H. E. 1980. Growth rate in oysters: an overdominant phetontype and its possible explanations. Evolution, 34, 856-867.

ZOUROS, E. AND FOLTZ D. W. 1984. Possible explanations of heterozygote deficiency in bivalve molluscs. Malacologia, $25,583-591$.

WRIGHT, S. 1943. Isolation by distance. Genetics, 28, 114-138. WRIGHT, S. 1965. The interpretation of population structure by $F$. statistics with special regard to systems of mating. Evolution, 19, 395-420.

WRIGHT, S. 1969. Evolution and the genetics of populations, vol. 3. The theory of gene frequencies. Univ. Chicago Press, Chicago.

SYTSMA K. J. AND SCHAAL, B. A. 1985. Genetic variation, differentiation, and evolution in a species complex of tropical shrubs based on isozymic data. Evolution, 39, 582-593 